\title{
Sexual and vegetative propagation of the medicinal Mexican species Phyllonoma laticuspis (Phyllonomaceae)
}

\author{
Ela Alcántara-Flores ${ }^{1}$, Alicia E. Brechú-Franco ${ }^{1 *}$, Angel Villegas-Monter ${ }^{2}$, Guillermo Laguna- \\ Hernández ${ }^{1} \&$ Armando Gómez-Campos ${ }^{1}$ \\ 1. Facultad de Ciencias, Universidad Nacional Autónoma de México, Avenida Universidad 3000, Colonia Universidad \\ Nacional Autónoma de México, C.U., Coyoacán 04510, México; aliciae@ciencias.unam.mx, elaalfl@hotmail.com, \\ glagher@ciencias.unam.mx, argocaz@hotmail.com \\ 2. Colegio de Post-graduados. Km. 36.5 Carretera México-Texcoco, C.P. 56230, Montecillo, Texcoco, Estado de \\ México; avillega@colpos.mx \\ * Correspondence
}

Received 15-X-2016. Corrected 04-IX-2016. Accepted 03-X-2016.

\begin{abstract}
Phyllonoma laticuspis leaves are used in Carrizal de Bravo, Guerrero, Mexico, to heal skin lesions such as injuries and smallpox sequelae and to treat diabetes mellitus type 2, and organic extracts of these leaves have been reported to exert antibacterial effects. High demand of $P$. laticuspis as a medicinal plant has decreased its natural populations, and propagation of the species has not yet been reported. Therefore, the purpose of this study was to assess the vegetative propagation of the species through cutting and air layering, as well as its sexual propagation in a preserved population. For this, concentrations of 1000,4000 and $6000 \mathrm{ppm}$ of a commercial root enhancer, with indole butyric acid (IBA), and a control treatment without IBA, were applied to the cuttings and air layers. Germination was evaluated under light and dark conditions using lots of freshly collected seeds and lots of seeds that had been stored for three months at $4{ }^{\circ} \mathrm{C}$ or $24 \pm 2{ }^{\circ} \mathrm{C}$. All experiments were performed in a completely randomized design. The cuttings did not develop roots in any concentration, whereas $100 \%$ of the air layers rooted, displaying vigorous roots in the presence of $4000 \mathrm{ppm}$ IBA, after four month of treatment application. Regarding germination, more than $60 \%$ of the freshly collected seeds germinated, whereas less than $20 \%$ of the seeds stored at $4{ }^{\circ} \mathrm{C}$, and close to $50 \%$ of the seeds stored at $24 \pm 2{ }^{\circ} \mathrm{C}$ germinated under light and dark conditions. No significant differences were observed between light and dark conditions, so they were categorized as indifferent photoblastic seeds. The observed moisture content of $13.5 \%$ and germination behaviour as the response to cold storage, suggest that the resultant seed quality was intermediate. P. laticuspis propagation for short-term foliage production can be carried out in air layers, in populations with a high density of adult plants as a source of plant material and for the restoration of disturbed areas, in the same locality. On the other hand, large-scale seedling production, medium-term foliage production and preservation of species variability can be achieved using seeds. Rev. Biol. Trop. 65 (1): 9-19. Epub 2017 March 01.
\end{abstract}

Key words: Phyllonoma laticuspis, air layers, cuttings, intermediate seeds, germination.

Phyllonoma laticuspis (Turcz.) Engl., (Phyllonomaceae) commonly known as "mil hojas" (thousand leaves), "cuendilla", "hierba de la viruela" (smallpox herb) or "encarnadora", is a wild plant with medicinal properties, as indicated by traditional knowledge. In Carrizal de Bravo, Guerrero, Mexico, P. laticuspis is applied directly on the skin in the form of poultices to heal wounds caused by cuts or abrasions and smallpox sequelae (Martinez,
1969). Plant-infused water obtained from the boiling of branches is also recommended to treat conditions associated with type 2 diabetes. Chemical analysis of extracts from the leaves of $P$. laticuspis revealed the presence of glycosides, phenols and terpenes, which have antibacterial effects according to biological assays (Vega-Castro, 2002).

The genus Phyllonoma of the monotypic family Phyllonomaceae was previously 
classified as a member of the Grossulariaceae and Saxifragaceae families. P. laticuspis is a bushy plant with epiphyllous inflorescences at or near the base of the leaf acumen, with globose to subglobose fruit, 5 to $7 \mathrm{~mm}$ long and 4.5 to $9 \mathrm{~mm}$ in diameter, crowned at the apex by calyx residues; 2 to 9 seeds per fruit, 1.5 to 2.5 by $0.9 \mathrm{~mm}$ long $1.7 \mathrm{~mm}$ wide. This species can be found in glens consisting of pine-oak mixed forest vegetation with elements of mountain cloud forest (MCF) (Pérez-Calix, 1999; Martínez-Gordillo, Cruz-Durán, Castrejón-Reyna, Jiménez-Ramírez, \& Ruíz-Jiménez, 2004). In El Triunfo Biosphere Reserve (Reserva de la Biósfera El Triunfo), Chiapas, Mexico, $P$. laticuspis is listed as vulnerable in the red list of the International Union for the Conservation of Nature (IUCN) (Martínez-Camilo, PérezFarrera, \& Martínez-Meléndez, 2012), whereas this species is regarded as endangered in the Bajio region in Michoacan State of, Mexico (Pérez-Calix, 1999).

Previous fieldwork conducted in Carrizal de Bravo, Guerrero, México, demonstrated that the high demand for P. laticuspis foliage and uncontrolled forest logging have diminished the population of this species. Moreover, the high regional demand and the need for large volumes of plants to satisfy therapeutic purposes require the development of propagation strategies to provide a continuous supply of chemically standardised plant material (Sahoo, Manchikanti, \& Dey, 2010). The present study was conducted to establish a propagation method for this species: a vegetative method to assess: the effect of different concentrations of an IBA phytohormone-based root enhancer, on the production of adventitious roots in cuttings and air layers of adult plants of $P$. laticuspis, as well as a sexual method for evaluating the germination of freshly collected and stored seeds, under light and dark conditions.

\section{MATERIALS AND METHODS}

The collection of branches and fruits and the elaboration of air layers were conducted in a preserved population of $P$. laticuspis located in an oak forest, $2 \mathrm{~km}$ from Cerro "El Huisteco" park, in the municipality of Tetipac, Guerrero, Mexico, at 2480 metres above sea level (18³5' N - 99॰36’39” W) (INEGI, 2000). The climate in this area is classified as $(\mathrm{A}) \mathrm{C}\left(\mathrm{w}_{2}\right)$ ig and is semi-warm and subhumid, with summer rainfall and low thermal oscillation (MartínezGordillo et al., 2004). The herborised samples of $P$. laticuspis were deposited in the Herbario de la Facultad de Ciencias (FCME) of the Universidad Nacional Autónoma de México, under reference voucher \#134824. Dilutions of a root enhancer containing IBA Radix ${ }^{\circledR} 10000$, an impregnable powder containing $1.0 \%$ indole3-butyric acid (Intercontinental Import Export, S.A. de C.V. Salamanca, State of Guanajuato, Mexico; CICOPLAFEST registration code: RSCO-3180/XII/94), with unscented talcum powder (bought at the drugstore) to concentrations of 1000,4000 and $6000 \mathrm{ppm}$ were used in the experiments for cuttings (De Klerk, Van der Krieken, \& De Jong, 1999; Ruiz-García, Vargas-Hernández, Cetina-Alcalá, \& VillegasMonter, 2005) and air layers (Chong, Allen, \& Barnes, 1992; Alves-de Oliveira, Carlos-Koller, \& Villegas-Monter, 1999). A control treatment, in which unscented talcum powder was applied without Radix ${ }^{\circledR}$ (0 IBA), was also included.

Cuttings were individualy planted in black plastic bags with a diameter of $18 \mathrm{~cm}$, containing a mixture of moistened peat-moss (Sphagnum) (SUNSHINE Peat Moss. Select Canadian Sphagnum. SKU:401015 5.5 CFC. Sun Gro Horticulture Canada Ltd. 52130 RR 65, P. O. Box 189. Seba Beach, AB TOE 2BO Canada) and perlite (Agrolita ${ }^{\mathrm{MR}}$, Agrolita de México, SA de CV, Mexico) at a ratio of 1:1 vol/vol. For air layers, only peat-moss was used as a substrate.

Vegetative propagation by cuttings: In March $20^{\text {th }} 2014$, eight mature shrubs, located in glens consisting of oak forest vegetation, were selected for the harvesting of 96 cuttings from fourteen to eighteen young branches with straight growth. The diameters of these branches ranged from 0.6 to $1 \mathrm{~cm}$. From each branch, five to eight cuttings that were 
25 to $30 \mathrm{~cm}$ in length were obtained. These cuttings were labelled with a number from 1 to 5 or 8 , starting at the base of the branch and moving towards the tip. The branches were then transported to the laboratory in a plastic box containing wet canvas to prevent their dehydration until the time of testing.

Cuttings were processed in a module with aseptic conditions, where they were disinfected with $0.2 \%$ Captan (Captan ${ }^{\circledR} 50 \mathrm{PH}$, Agricultural Fungicide Wettable powder. Active ingredient: Captan: N-trichloromethylthio4-cyclohexene-1,2-dicarboximide, not less than: $50.0 \%$, equivalent to $500 \mathrm{~g}$ of $\mathrm{AI} / \mathrm{kg}$ Bayer of Mexico, SA de CV, Bayer CropScience Division Blvd. M. de Cervantes Saavedra No. 259. Col. Granada. 11520 Mexico, DF) and rinsed three times with sterile water. Three longitudinal incisions on the base of the stakes were made with penknife and cuttings were cut $1 \mathrm{~cm}$ at the basis with secateurs, both instruments disinfected with chlorine $(20 \%)$. The basal section of cuttings (approximately $2 \mathrm{~cm}$ ) was immersed in one of the three dilutions of the root enhancer product Radix ${ }^{\circledR}$, then excess was removed, and three to four buds were buried in the substrate. Each bag contained one cutting, and four bags were placed on a tray, and covered with transparent polyethylene plastic to preserve the environment humidity. Trays were randomly distributed along the greenhouse sides to avoid any bias due to differentials within the greenhouse environment. Manual spray irrigation was performed every three days to create a humidity-saturated environment. A shade cloth $35 \%$ (Hidroenvironment; Avenida Toltecs number 41, Colonia San Javier. Tlalnepantla, Estado de Mexico. C.P. 54030) generated an atmosphere of filtered light, similar to that received by $P$. laticuspis under the canopy of oak trees. Testing was conducted from March to June 2014, under greenhouse conditions at $24 \pm 4{ }^{\circ} \mathrm{C}$ under a relative humidity of $56 \%$ (Blazich, 1988; Hartman \& Kester, 1989; Rochefort \& Vitt, 1990).

Random selection was performed to ensure the presence of cuttings with different thickness for the four treatments. The experiments, with four replication of six cuttings each, were carried out for the evaluation of three treatments with IBA root enhancer (1000, 4000 and 6000 ppm) and a control (0 IBA) with unscented talcum powder application alone, to integrate a randomised $4 \times 6 \times 4$ experimental design.

\section{Vegetative propagation by air layers:}

The technique of air layering removes a ring of the phloem layer and interrupts the flow of sugars and photosynthates, that congregate there. This accumulation, in the presence of rooting hormone and moist substrate covered by a plastic sheet, stimulates the development of adventitious roots in the area of the wound. Air layering was performed in this way on March $20^{\text {th }} 2014$, using 24 mature shrubs that had not been used to harvest cuttings. Branches with a thickness of 1 to $2 \mathrm{~cm}$ were subjected to girdling by means of a $2 \mathrm{~cm}$-wide incision. The doses corresponding to the four treatments used in cuttings were subsequently applied to the girdles to promote rooting. The incision was subsequently covered with moistened peat-moss and wrapped with plastic, which was firmly tied at the ends to achieve a humid environment favouring rooting (Hartman, \& Kester, 1989). The air layers were inspected for the presence of roots every two months, from March to September.

Four treatments were tested, each with six replicates: three doses of IBA $(1000,4000$ and $6000 \mathrm{ppm}$ ) and a control (0 IBA) with talc application alone. Each shrub was randomly assigned with four doses to complete six repetitions for each treatment, to integrate a randomised 4 × 6 experimental design.

Sexual propagation: Mature white-coloured fruits of approximately $8 \mathrm{~mm}$ in diameter were collected on April $4^{\text {th }} 2014$ from eight shrubs (Fig. 1). A total of 3600 seeds were separated, eliminating the pulp of the fruit. After this procedure, seeds were washed and left to dry for two days at laboratory temperature $\left(24{ }^{\circ} \mathrm{C}\right)$. Two groups were formed: one comprising 1200 freshly collected seeds and another consisting of 2400 seeds to be stored. 

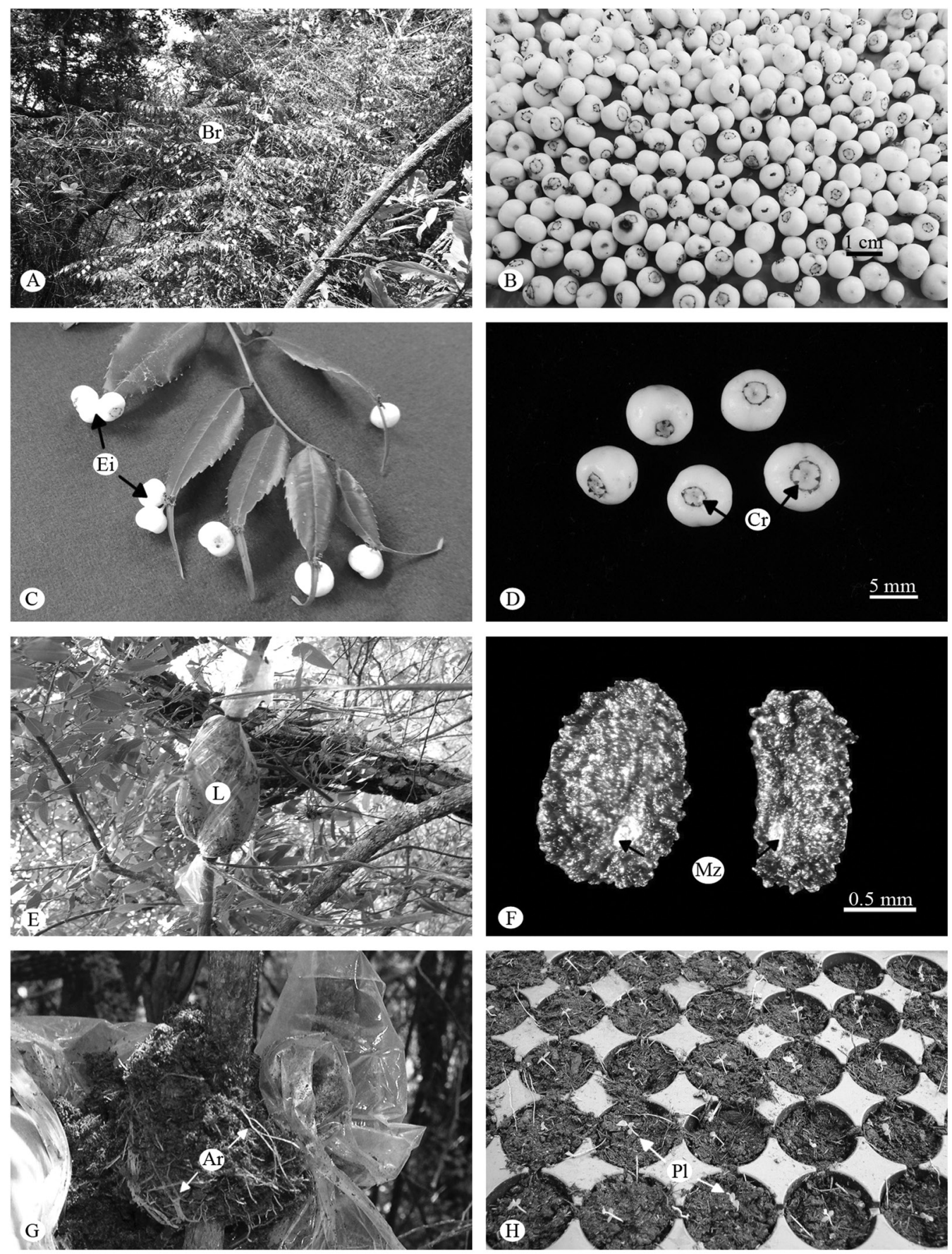

Fig. 1. Phyllonoma laticuspis. Propagation and morphological data. A. Shrub with abundant side branches (Br). B. Variability in fruit size. C. Leaves with epiphyllous infructescences (Ei) at the base of acumen. D. Fruits crowned by calyx residues $(\mathrm{Cr})$. E. Air layer (L). F. Seeds showing the mycropilar zone (Mz) and the rough seed coat. G. Adventitious roots (Ar) in 4000 ppm layering with IBA and four months of treatment. H. Transplanted seedlings (Pl). 
Sowing procedure was carried out in transparent plastic trays with lids, containing a mixture of peat-moss and soil at a ratio of $1: 1 \mathrm{vol} /$ vol, which was moistened with running water. After sowing, the boxes were closed, labelled, and incubated in a Lab-Line Biotronette Plant Growth Chamber (Lab-Line Instruments, INC. Designers and Manufacturers, Melrose Park, Ill, USA) maintained at $24 \pm 2{ }^{\circ} \mathrm{C}$ with a 12 $\mathrm{h}$ light/day cycle, and a relative humidity of approximately $65-75 \%$. Light was controlled using cool white fluorescent lamps with a very high intensity $\left(500 \mathrm{mM} \cdot \mathrm{m}^{-2} . \mathrm{s}\right)$. Weekly recording of emerged seedlings was carried out for three months.

Freshly collected test: Using the freshly collected seeds, 12 lots containing 100 seeds each were sown in transparent plastic trays with lids. Six lots placed under light conditions were covered with a transparent plastic, and the other six under dark conditions, were covered with a black plastic. Both treatments were subjected to the same incubation conditions.

An experimental unifactorial $2 \times 6$ design was employed to assess the effect of the light/ dark conditions in the six repetitions.

Storage tests: A total of 2400 seeds were used; these were divided into two groups of 1200 seeds each. Each seed group was deposited in six jars with lids, which were covered with aluminium foil and stored for three months, one at $4{ }^{\circ} \mathrm{C}$ and the other in the abovementioned incubator at $24 \pm 2{ }^{\circ} \mathrm{C}$.

After three months of storage at $4{ }^{\circ} \mathrm{C}$ or $24 \pm 2{ }^{\circ} \mathrm{C}, 12$ lots with 100 seeds each were formed from these groups. Of these lots, six were incubated in light conditions and six in dark conditions in a Lab-Line Biotronette Plant Growth Chamber incubator, following the procedure described previously for the freshly collected seeds (with the above-mentioned specifications).

A random multifactorial $2 \times 2 \times 6$ experimental design was used, considering two storage temperatures $\left(4^{\circ} \mathrm{C}\right.$ and $\left.24 \pm 2{ }^{\circ} \mathrm{C}\right)$ and two lightning conditions for germination (light and darkness), with six repetitions.

The data from vegetative and sexual propagation were recorded as percentages, and arcsine transformation was then applied to perform ANOVA with Statgraphics Plus. When the analysis detected significant differences between treatments, they were characterised through a Tukey multiple range test.

Fruit and seed measurements: The interpretation of the sexual propagation results was supported by measurements of different fruit and seed characteristics. For linear measurements of the fruit, a digital caliper was used (Mitutoyo Digimatic Caliper, $150 \mathrm{~mm} 6$ in, Mitutoyo Corporation, Japan); whereas for weight measurements, an analytical balance was utilised (SCIENTECH ${ }^{\circledR}$ SA 120, SCIENTECH INC. 5649 Arapahoe Ave, Boulder, CO 80303, USA).

From the collected sample, 100 fruits were randomly selected, and the following average parameters were determined: fruit size based on diameter and length, fruit weight, the number of seeds per fruit, the percentage of empty seeds, seed weight and seed size. The size of the seeds was calculated by measuring their length and width from scaled photographs taken with a Cannon Power Shot A640 camera adapted to a Zeiss stereoscopic microscope STEMI DV4, using the digital image processing programme AxioVision (Carl-Zeiss-Promenade 10, 07745 Jena, Germany). Comparison of measurements was made with data of Perez-Calix (1999).

The moisture content in the seeds was calculated by measuring the loss of weight in four lots of 100 seeds each, after 17 hours of exposure at $100{ }^{\circ} \mathrm{C}$ in a RiosRocha 4433 drying kiln (Calle 23 60, Olivar del Conde $2^{\text {da }}$ Secc, 01408 Ciudad de Mexico, DF).

\section{RESULTS}

Vegetative propagation by cuttings: The cuttings produced shoots and leaves within one month, which lasted for three months, at which point they began to wilt. Upon removal 
of the cuttings, it was noted that the buried end had not developed roots; after three months of being planted, there was no survival of any cutting.

Vegetative propagation by air layers: Inspection at two months revealed the appearance of root primordia in most of the air layers, and at four months, $100 \%$ rooting was achieved in all four treatments. The developed roots were plentiful but showed some morphological differences (Table 1).

Sexual propagation: Freshly collected seeds incubated at $24 \pm 2{ }^{\circ} \mathrm{C}$ exhibited an emergence percentage of $63 \%$ in light conditions (Standard Deviation, $\mathrm{SD}=3.4$, Number of cases, $\mathrm{N}=6$ ) or $64 \%$ in dark conditions ( $\mathrm{SD}=$ $3, \mathrm{~N}=6$ ). No significant differences were evident between the two treatments (Tukey $=0.39$, $\mathrm{P}=0.5441)$.

The group of seeds stored at $24 \pm 2{ }^{\circ} \mathrm{C}$ showed an emergence percentage of $51 \%$ in light conditions $(\mathrm{SD}=1.8, \mathrm{~N}=6)$ and $53 \%$ in dark conditions $(\mathrm{SD}=3.3, \mathrm{~N}=6)$. The seeds stored at $4{ }^{\circ} \mathrm{C}$ reached a maximum emergence percentage of $15 \%$ in light conditions $(\mathrm{SD}=$ $2.8, \mathrm{~N}=6$ ) and $17 \%$ in dark conditions $(\mathrm{SD}=3.3, \mathrm{~N}=6)$.

A significant difference was found between the groups of seeds stored at $4{ }^{\circ} \mathrm{C}$ and $24 \pm 2{ }^{\circ} \mathrm{C}$ in both light and dark conditions (Tukey $=246.44, \mathrm{P}=0.0001$ ). Tukey's test revealed no significant differences in the responses of the two groups of stored seeds to light and dark conditions (Tukey $=2.73, \mathrm{P}=$ $0.1131)$. Moreover, no emergence was observed after three months (Fig. 2).

Fruit and seed measurements: The average measurements of the $P$. laticuspis fruits and seeds appear in table 2 .

\section{DISCUSSION}

The various treatments with Radix ${ }^{\circledR} 10000$ assessed in this study did not promote rooting in cuttings. The development of buds and leaves on lateral buds resulted in the depletion of plant reserves (Howard, \& Nahlawi, 1969) and deterioration and death of tissues within three months. Leaf sprouting may have an inhibitory

TABLE 1

Effect of IAB on the rooting and root characteristics of $P$. laticuspis air layers, at four months after application

\begin{tabular}{|c|c|c|c|c|}
\hline $\begin{array}{l}\text { IBA treatments } \\
\qquad(\mathrm{ppm})\end{array}$ & $\begin{array}{l}\text { Air layering rooted } \\
(\%)\end{array}$ & $\begin{array}{l}\text { Root length } \\
\quad(\mathrm{cm})\end{array}$ & Number of roots & $\begin{array}{l}\text { Root color } \\
\text { and thickness }\end{array}$ \\
\hline 0 & 100 & 0.5 to 5 & 20 & Hyalines and $1 \mathrm{~mm}$ \\
\hline 1000 & 100 & 0.5 to 5 & 28 & Hyalines and $1 \mathrm{~mm}$ \\
\hline 4000 & 100 & $>10$ & $>50$ & Whitish and 3 to $5 \mathrm{~mm}$ \\
\hline 6000 & 100 & $>15$ & $>50$ & Whitish and 1 to $3 \mathrm{~mm}$ \\
\hline
\end{tabular}

TABLE 2

Measurements of $P$. laticuspis fruits and seeds, their characteristics and comparison with those reported by Perez-Calix (1999) (percentage or mean \pm SD)

\begin{tabular}{lcc}
\multicolumn{1}{c}{ Parameter } & Percentage or mean $\pm \mathrm{SD}$ & Pérez-Calix (1999) \\
Fruit size (diameter x length) $(\mathrm{mm})$ & $8 \pm 0.6 \times 6.7 \pm 0.7$ & 5 to $7 \times 4.5$ to 9 \\
Fruit weight $(\mathrm{mg})$ & $196.1 \pm 38$ & Not reported \\
$\mathrm{N}^{\circ}$ seeds per fruit & 4 with range of 1 to 11 seeds & 2 to 9 seeds \\
Empty seeds $(\%)$ & 28.3 & Not reported \\
Seed size (length $\mathrm{x}$ width) $(\mathrm{mm})$ & $1.7 \pm 0.3 \times 1.0 \pm 0.2$ & 1.5 to $2.5 \times 0.9$ to 1.7 \\
Seed weight $(\mathrm{mg})$ & $1.4 \pm 0.8$ & Not reported \\
Seed moisture content $(\%)$ & $13.5 \pm 0.002$ & Not reported \\
\hline
\end{tabular}




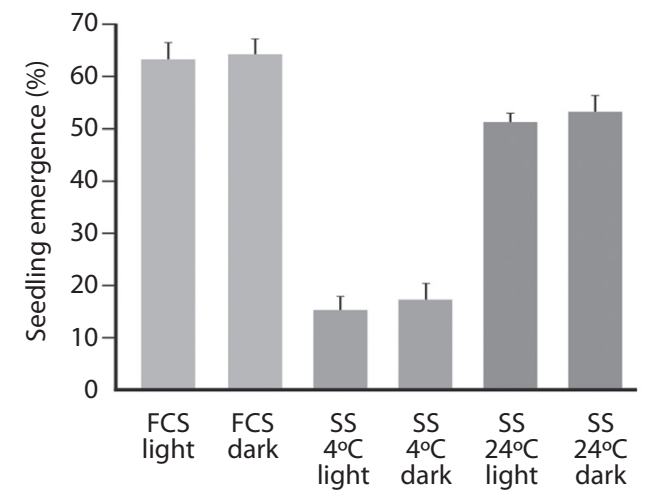

Fig. 2. Emergence of seedlings from freshly collected seeds (FCS) of $P$. laticuspis and seeds stored (SS) for three months at $4{ }^{\circ} \mathrm{C}$ or $24 \pm 2{ }^{\circ} \mathrm{C}$, germinated under light and dark conditions. The germination temperature was $24 \pm 2{ }^{\circ} \mathrm{C}$. Mean \pm standard deviation (ANOVA, $\mathrm{P}_{35,5}>0.0001$ ).

effect on rooting, as the reserves of the cutting shifted towards shoots undergoing active growth, and not towards root stimulation (Howard, \& Nahlawi, 1969). Inhibition of rooting cuttings may be associated with the generation of an inhibitor of rooting in tissues that form the basis of the stake, as has been proposed in stem cuttings of Eucalyptus grandis (Paton, Willing, Nicholls, \& Pryor, 1970).

The leaf sprouting that occurred in the cuttings was probably due to exposure of the aerial part of the cuttings to a warm atmosphere with an average temperature of $24{ }^{\circ} \mathrm{C}$, while the damp substrate, together with the applied irrigation, reduced the temperature to create a cooler environment. This equal or lower temperature of the substrate in relation to the temperature experienced by the aerial parts of plants, has been reported as a factor promoting leaf development in cuttings of the forest species Triplochiton scleroxylon (Leakey, Chapman, \& Longman, 1982).

Handling cuttings for clonal propagation is complex because various factors must be considered, such as environmental and plant characteristics. For example, some species require full light, whereas others require limited radiation; the substrate quality, the size of the cuttings and the maturity stage of the donors are also relevant (Mesén, 1998; Ruiz García et al.,
2005). Although, for the trial with P. laticuspis, the cuttings were placed in a greenhouse with limited irradiation, simulating the light it receives in the forest, no rooting was achieved. This response could be related to the high light availability, like in Begonia decandra, which after seven months in light gaps and understories microenvironments, growth parameters as height, biomass and leaf area of cuttings were very sensitive to increases in light as the main resource (Cordero, 2000).

The Sphagnum substrate used in this work, maintained adequate moisture, according to suppliers of peat-moss; it is suitable for seed germination, seedling growth and vegetative propagation of species (Rochefort, \& Vitt, 1990). Some providers mention that peat-moss maintains an acidic $\mathrm{pH}$ (5.8) and provides nutrients (Verdtical. Calle Doctor Rizal 808016 Barcelona, España). However, it is important to try with different substrates such as gravel, sand and sawdust, which have showed high percentages of rooting from cuttings in timber species (Mesén, Newton, \& Leakey, 1997).

The emergence of root primordia in air layers, occurred with a continuous vertical linear pattern above the cut area, extending towards the distal region of the branch, which may indicate an origin from ray cells. The sites of origin for the formation of adventitious roots in stem cuttings are vascular bundles or nearby areas. However, Haisig (1974) considers the site of root initiation to depend on whether the primordia are induced or preformed; such primordia may develop in the cambium, phloem, pericycle and cells adjacent to the bundles, where roots have most commonly been observed.

Vegetative propagation by air layers and IBA treatments in P. laticuspis resulted in a higher amount of roots than in control treatment, but the cause of varied thickness of the roots between 4000 and 6000 treatments are unknown. Other studies have reported that exogenous application of auxins as IBA, resulted in increased percentage of lateral roots in woody plants such as Prunus spp. (Stefancic, Stampar, \& Osterc, 2005; Tchoundjeu et al., 
2002), and in Swietenia macrophylla (Hossain, Islam, \& Hossain, 2004). Rooting mechanism may depend on the species and different intrinsic and extrinsic factors, for example, the average of dry weight of roots induced by IBA was significantly increased in both $S$. macrophylla and $C$. velutina, but few and vigorous roots were produced in the $S$. macrophylla cuttings compared to fine roots of the $C$. velutina cuttings (Hossain et al., 2004).

P. laticuspis air layering resulted such a successful technique to initiate adventitious roots stem, so that root production was better than cutting, as it occurs in vegetative propagation of Cecropia obtusifolia (LaPierre, 2001).

Based on the results of the present study, air layering is a feasible propagation method for P. laticuspis in spite of the occurrence of late rooting, which lasted from four to six months, and the differences in the morphological characteristics of the roots obtained with the three concentrations of IBA. However, the roots obtained in P. laticuspis with the 4000 ppm IBA treatment were white and thicker (3 to $5 \mathrm{~mm}$ ), allowing the development of more vigorous organs. Therefore, this concentration could be recommended for the species propagation. Germination of the freshly collected seeds demonstrated that $63 \%$ to $64 \%$ were quiescent.

Dark conditions did not improve the emergence of $P$. laticuspis seeds. Consequently, the seeds were classified as light-indifferent seeds (Vázquez-Yanes, \& Orozco Segovia, 1992; Figueroa, \& Vázquez-Yanes, 2002), as reported for the species Hibiscus elatus found in cloud forests (Sánchez, Muñoz, \& Montejo, 2003), a type of vegetation that also hosts $P$. laticuspis.

Constraints on obtaining higher percentages may be associated with the presence of $28 \%$ empty seeds, as discovered during fruit and seed parameter measurements. The remaining $9 \%$ may represent seeds that are physiologically dormant due to an immature embryo (Eurola, 1972). Reports on the germination of species in the Grossulariaceae and Saxifragaceae families indicate the existence of some species in Arctic environments with non-dormant seeds, such as Saxifraga caespito$s a$ (Bell, \& Bliss, 1980), as well as species with physiological dormancy, such as Saxifraga hieracifolia (Eurola, 1972), but do not discuss their desiccation tolerance. The emergence ability of $P$. laticuspis seeds stored in dry conditions decreased at both tested temperatures, with a reduction of $18 \%$ being observed in the case of seeds stored at $24 \pm 2{ }^{\circ} \mathrm{C}$ and $72 \%$ for seeds stored at $4{ }^{\circ} \mathrm{C}$, indicating a severe effect of cold temperatures on longevity.

The moisture content of freshly collected seeds $(13.5 \pm 0.002 \%)$ and the lack of tolerance to cold storage, which resulted in $15 \%$ to $17 \%$ emergence, classify $P$. laticuspis seeds as intermediate (Ellis, Hong, \& Roberts, 1990; León-Lobos, \& Ellis, 2002), since the percentage of emergence following storage at $24 \pm$ $2{ }^{\circ} \mathrm{C}$ was significantly higher, and there was a relatively small reduction with regard to the emergence of freshly collected seeds.

The classification of Coffea arabica (Ellis et al., 1990) as well as Fagus sylvatica and F. crenata as intermediate seeds (León-Lobos, \& Ellis, 2002) highlights the fact that these seeds tolerate some degree of desiccation. However, their longevity under dry storage conditions is reduced when the temperature is below $10{ }^{\circ} \mathrm{C}$.

The parameters of the fruits and seeds of P. laticuspis from Cerro El Huisteco area generally coincided with the values recorded by Pérez-Calix (1999). Only the diameter of the collected fruits $(8 \mathrm{~mm})$ was greater than the reported range of 5 to $7 \mathrm{~mm}$. The seeds of $P$. laticuspis share the following characteristics with the Grossulariaceae and Saxifragaceae families: small size; fleshy tissues that cover the seed coat as an aril or sarcotesta of gelatinous pulp; albuminous nature with a small or tiny embryo; and endosperm containing oily food reserves (Corner, 1976). Considering the average seed weight $(1.4 \pm 0.8 \mathrm{mg})$ and fruit weight $(196.1 \pm 38 \mathrm{mg})$ of $P$. laticuspis, the pulp accounts for more than $90 \%$ of the fruit weight, providing the seeds with a moistened environment that prevents from dehydration.

The orography of the collection area, corresponding to a preserved oak forest, 
consists of rugged slopes, volcanic soils with spaces between the rocks and high accumulation of leaf litter. The climate is semi-warm and subhumid, with summer rainfall and low thermal oscillations, being characterised by temperatures between $22{ }^{\circ} \mathrm{C}$ and $30{ }^{\circ} \mathrm{C}$ and annual rainfall between 1280 and $1800 \mathrm{~mm}$ (Martínez-Gordillo et al., 2004). Under these conditions, $P$. laticuspis blooms and bears fruit during most of the year, and the fruits may fall off and penetrate the leaf litter or rock spaces, leaving the seeds exposed to weak desiccation and to the lower temperatures of these deeper levels of soil, as occurs in recalcitrant seeds like Alibertia patinoi (Rubiaceae) in which the pulp represents $88 \%$ of the total weight (Escobar, \& Torres, 2013). In these, favourable conditions, a survival of approximately $60 \%$ of seeds may occur until the next rainy season, considering the light-indifferent characteristics of the seeds, as was reported in recalcitrant seed bank of Podocarpus angustifolius (Ferrandis, Bonilla, \& Osorio, 2011). Determination of average number of seeds produced per fruit, the percentage of viable and non-viable seeds and the knowledge that are intermediate seeds, suggests the main survival strategy of $P$. laticuspis is to keep their populations through seed germination in situ, regarding the short extension of the viability period of their intermediate seeds, as was shown in non-ortodox seeds like Theobroma and Araucaria (Barbedo et al., 2013).

One year after sowing, the plants produced from seeds reached a height of $30 \mathrm{~cm}$ and were donated to the inhabitants of Carrizal de Bravo, as were the plants obtained through air layering. The results obtained in the present study constitute as a basis for proposing these propagation methods for conservation programmes that allow preservation of the existing vegetation in the region. In the case of sexual propagation, the results revealed that this method is useful for large-scale culture. $P$. laticuspis represents an important economic and medical resource, and its cultivation would allow a continuous supply of chemically standardised plant material (Sahoo, et al., 2010) that is safe for direct consumption, or can be used as raw material for the development of phytomedicines or nutraceuticals. In summary, air layering was found to be a feasible method for the vegetative propagation of $P$. laticuspis for short-term foliage production. Propagation of freshly collected seeds was found to be effective for large-scale seedling production, medium-term foliage production and preservation of species variability. The community of Carrizal de Bravo could apply both methods for the plants they protect, in conservation programmes and for the large-scale cultivation of the species.

\section{ACKNOWLEDGMENTS}

We thank the following academic staff of the UNAM Faculty of Sciences (Facultad de Ciencias): Martha Juana Martínez Gordillo, from the FCME Herbarium, for plant identification; Patricia Olguín Santos, for the use of the greenhouse; Ana Isabel Bieler-Antolín and Alfonso Bautista-García, for image processing; and María Eugenia Muñíz-Díaz-de-León, for technical support. We also thank the National Forestry Commission (Comisión Nacional Forestal, CONAFOR, Mexico) for their support of the CONAFOR 41828 Project.

\section{RESUMEN}

Propagación sexual y vegetativa de la especie medicinal mexicana Phyllonoma laticuspis (Phyllonomaceae). Las hojas de Phyllonoma laticuspis se utilizan en Carrizal de Bravo, Gro. México, para curar lesiones de la piel como heridas, secuelas de viruela y afecciones de la diabetes mellitus tipo 2. Los extractos orgánicos de hojas, mostraron efectos antibacterianos. La gran demanda de $P$. laticuspis como planta medicinal, ha disminuido sus poblaciones naturales, y no existen reportes de la propagación de la especie. Por lo tanto, el propósito del presente trabajo fue evaluar la propagación vegetativa de la especie a través de estacas y acodos, y su propagación sexual en una población conservada. En la propagación por estacas y acodos se aplicaron concentraciones de 1000,4000 y 6000 ppm de un enraizador comercial con ácido indolbutírico (AIB), y un tratamiento control sin AIB. La germinación se evaluó en luz y oscuridad mediante el uso de lotes de semillas recién recolectadas y lotes de semillas almacenadas por tres meses a $4{ }^{\circ} \mathrm{C}$ y a $24 \pm 2{ }^{\circ} \mathrm{C}$. Todos los experimentos se realizaron en un diseño completamente al azar. Las estacas 
no desarrollaron raíces en ninguna de las concentraciones, mientras que el $100 \%$ de los acodos enraizaron, produciendo raíces vigorosas con la concentración de 4000 ppm de AIB, a los cuatro meses de la aplicación. Con respecto a la germinación bajo condiciones de luz y oscuridad, las semillas recién recolectadas germinaron más del $60 \%$, mientras que las semillas almacenadas a $4{ }^{\circ} \mathrm{C}$ menos del $20 \%$ y las almacenadas a $24 \pm 2{ }^{\circ} \mathrm{C}$ cerca del $50 \%$. No hubieron diferencias significativas entre la germinación en luz y oscuridad, por lo que se consideraron como semillas fotoblásticas indiferentes. El contenido de humedad de $13.5 \%$ y el comportamiento de la germinación en respuesta al almacenamiento en frío, sugieren la cualidad de semillas de tipo intermedias. La propagación de P. laticuspis para la producción de follaje a corto tiempo, puede hacerse por acodos en poblaciones con alta densidad de plantas adultas como fuente de material vegetal y para la restauración de áreas alteradas en la misma localidad. Mientras que la producción de follaje a mediano plazo y la conservación de la variabilidad de la especie, se puede lograr con la obtención masiva de plántulas a través de semillas.

Palabras clave: Phyllonoma laticuspis, acodos, estacas, semillas intermedias, germinación.

\section{REFERENCES}

Alves-de Oliveira, A., Carlos-Koller, O., \& Villegas-Monter, A. (1999).Propagación vegetativa de aguacate selección 153 (Persea sp.) por acodo en contenedor. Revista Chapingo Serie Horticultura, 5, 221-225.

Bell, K. L., \& Bliss, L. C. (1980). Plant reproduction in a high artic environment. Artic and Alpine Research, $12,1-10$.

Blazich, F. A. (1988). Chemicals and formulations used to promote adventitious rooting. In T. D. Davis, B. E. Haissig, \& N. Sankhla (Eds.), Adventitious root formation in cuttings (pp. 132-149). Portland, Oregon: Dioscorides.

Cordero, R. A. (2000). Effect of two naturallight regimes and nutrient addition on the forest herb Begonia decandra (Begoniaceae). Revista de Biología Tropical, 48, 579-586.

Corner, E. J. H. (1976). The Seeds of Dicotyledons. London, Great Britain: Cambridge University Press.

Chong, C., Allen, O. B., \& Barnes, H. W. (1992). Comparative rooting of stem cuttings of selected woody landscape shrub and tree taxa to varying concentrations of IBA in talc, ethanol and glycol carriers. Journal of Environmental Horticulture, 10, 245-250.

De Klerk, G. J., Van der Krieken, W., \& De Jong, J. C. (1999). The formation of adventitious roots: new concepts, new possibilities. In Vitro Cellular \& Developmental Biology - Plant, 35, 189-199.
Ellis, R. H., Hong, T. D., \& Roberts, E. H. (1990). An intermediate category of seed storage behaviour? I. Coffee. Journal of Experimental Botany, 41, 1167-1174.

Escobar, D. F., \& Torres, A. M. (2013). Morphology, ecophysiology and germination of seeds of the Neotropical tree Alibertia patinoi (Rubiaceae). Revista de Biología Tropical, 61, 547-556.

Eurola, S. (1972). Germination of seeds collected in Spitsbergen. Annales Botanici Fennici, 9, 149-159.

Ferrandis, P., Bonilla, M., \& Osorio, L. C. (2011). Germination and soil seed bank traits of Podocarpus angustifolius (Podocarpaceae): an endemic tree species from Cuban rain forests. Revista de Biología Tropical, 59, 1061-1069.

Figueroa, J. A., \& Vázquez-Yanes, C. (2002). Efecto de la calidad de la luz sobre la germinación de semillas en el árbol pionero tropical Heliocarpus appendiculatus (Tiliaceae). Revista de Biología Tropical, 50, 31-36.

Haisig, B. E. (1974). Origins of adventitious roots. Journal of Forestal Science, 4, 299-310.

Hartmann, H. T., \& Kester, D. E. (1989). Propagación de Plantas. Principios y prácticas. México, Calzada de Tlalpan 5022, México 22, D. F.: Compañía Editorial Continental, S. A. de C. V.

Hossain, M. A., Islam, M. A., \& Hossain, M. M. (2004). Rooting ability of cuttings of Swietenia macrophylla King and Chukrasia velutina Wight et Arn as influenced by exogenous hormone. International Journal of Agriculture \& Biology, 6, 560-564.

Howard, B. H., \& Nahlawi, N. (1969). Factors affecting the rooting of plum Harwood cuttings. Journal of Horticultural Science, 44, 303-310.

INEGI (Instituto Nacional de Estadística y Geografía) (2000). www.inegi.gob.mx.

LaPierre, L. M. (2001). Vegetative propagation of Cecropia obtusifolia (Cecropiaceae). Revista de Biología Tropical, 49, 973-976.

Leakey, R. R. B., Chapman, V. R., \& Longman, K. A. (1982). Physiological studies for tropical tree improvement and conservation. Factors affecting root initiation in cuttings of Triplochiton scleroxylon $\mathrm{K}$. Schum. Forest Ecology and Management, 4, 53-66.

León-Lobos, P., \& Ellis, R. H. (2002). Seed storage behavior of Fagus sylvatica and Fagus crenata. Seed Science Research, 12, 31-37.

Martínez, M. (1969). Las Plantas Medicinales de México. México D.F.: Ediciones Botas.

Martínez-Camilo, R., Pérez-Farrera, M. A., \& MartínezMeléndez, N. (2012). Listado de plantas endémicas 
y en riesgo de la Reserva de la Biosfera El Triunfo, Chiapas, México. Botanical Sciences, 90, 263-285.

Martínez-Gordillo, M., Cruz-Durán, R., Castrejón-Reyna, J. P., Jiménez-Ramírez, J., \& Ruíz-Jiménez, C. A. (2004). Flora Vascular de la porción Guerrerense de la Sierra de Taxco, Guerrero, México. Anales del Instituto de Biología. Serie Botánica, 75, 105-189.

Mesén, F., Newton, A. C., \& Leakey, R. R. B. (1997). Vegetative propagation of Cordia alliodora (Ruiz \& Pavon) Oken: the effects of IBA concentration, propagation medium and cutting origin. Forest Ecology and Management, 92, 45-54.

Mesén, F. (1998). Enraizamiento de estacas juveniles de especies forestales: uso de propagadores de subirrigación (Serie técnica, Manual Técnico No. 30). Turrialba, Costa Rica: CATIE.

Paton, D. M., Willing, R. R., Nicholls, W., \& Pryor, L. D. (1970). Rooting of stem cuttings of Eucalyptus: A rooting inhibitor in adult tissue. Australian Journal of Botany, 18, 175-183.

Pérez-Calix, E. (1999). Phyllonomaceae. Flora del Bajio $y$ de Regiones Adyacentes. Pátzcuaro, Michoacán, México: Instituto de Ecología, A.C. Centro Regional del Bajío.

Rochefort, L., \& Vitt, D. H. (1990). Growth, production, and decomposition dynamics of Sphagnum under natural and experimentally acidified conditions. Ecology, 71, 1986-2000.
Ruiz-García, R., Vargas-Hernández, J. J., Cetina-Alcalá, V. M., \& Villegas-Monter, A. (2005) Efecto del Ácido Indolbutírico (AIB) y tipo de estaca en el enraizado de Gmelina arborea Roxb. Revista Fitotecnia Mexicana, 28, 319-326.

Sahoo, N., Manchikanti, P., \& Dey, S. (2010). Herbal drugs: Standards and regulation. Fitoterapia, 81, 462-71.

Sánchez, J. A., Muñoz, B., \& Montejo, L. (2003). Efectos de tratamientos robustecedores de semillas sobre la germinación y establecimiento de árboles pioneros bajo condiciones de estrés. Ecotrópicos, 16, 91-112.

Stefancic, M., Stampar, F., \& Osterc, G. (2005). Influence of AIA on root development and quality of Prunus 'GiSe1A5' leafy cuttings. HortScience, 40, 2052-2055.

Tchoundjeu, Z., Avana, M. L., Leakey, R. R. B., Simons, A. J., Assah, E., Duguma, B., \& Bell, J. M. (2002). Vegetative propagation of Prunus africana: effects of rooting medium, auxin concentrations and leaf area. Agroforestry Systems, 54, 183-192.

Vázquez-Yanes, C., \& Orozco-Segovia, A. (1992). Effects of litter from a tropical rainforest on tree seed germination and establishment under controlled conditions. Tree Physiology, 11, 391-400.

Vega-Castro, C. (2002). Análisis de los extractos orgánicos de la lámina foliar de Phyllonoma laticuspis (Phyllonomaceae) una especie empleada en la medicina tradicional (Tesis de Licenciatura). Universidad Nacional Autónoma de México, México, D. F. 
